\title{
TEN YEARS OF FLORIDA'S "WHO GAVE IT-WHO GOT IT" LAW
}

\author{
ELSTON ROADY*
}

Ten years and four gubernatorial elections ago, Florida legislators passed the "Who Gave It-Who Got It" law, ${ }^{1}$ a comprehensive attempt to adjust state regulation of campaign finances to the facts of contemporary political life. One of the key provisions of this unique experiment has been the requirement of complete publicity for all expenditures and all contributions in campaigns for elective office. ${ }^{2}$ Each person involved in financing the campaign-the donor, the treasurer, and the candidate -is legally responsible for the accuracy of the contributions and expenditures reports required by the law. The publicity resulting from these reports has kept the Florida voter informed of all money involved in political contests so that, before he votes, he can know the amount received by each candidate, the identity of contributors and the amount contributed by each donor, and the amount of expenditures and the type of expenditures made by each candidate. This has been a protection both for candidates and voters, for it has made more difficult the undetected entry of special interest money into Florida campaigns. It is the informed judgment of those who should know that this law has diminished corrupting influences frequently associated with money in elections and that Florida voters have been given an excellent profile of financial support of all candidates before the lever is pulled in the voting booth.

The official reports show that the cost of campaigning for governor has gone up seventy-three per cent in this ten-year period. Yet, while the population of Florida increased almost eighty-eight per cent in the $195^{0}-1960$ decade, there has been only an eighteen per cent increase in the votes cast for governor. The significant increase in the cost of campaigning is reflected in a breakdown of the cost-per-vote in three gubernatorial races which appears below. ${ }^{3}$ The rate and magnitude of expenditures in 1960 seemed to some political observers to go beyond the saturation point. However, candidates enter the race to win, and are reluctant to leave any stone unturned.

Although expenditures increased seventy-three per cent during this ten-year period, contributions increased seventy-six per cent. Yet, the total number of con-

* B.Ed. 1942, Illinois State Normal University; M.A. x947, Ph.D. I951, University of Illinois. Professor of Government and Director of the Florida Center for Education in Politics, Florida State University. Author, Two Worlds in Conflict (I957), Model State Campaign Contributions and Expenditures REPORTING LAW (Ig6r), and various articles on Florida politics. Contributor to legal and political science periodicals.

${ }^{1}$ Fla. Laws 195I, ch. 26870 , FzA. Stat. ANs. $\$ 99.16$ I (1960).

'See the Appendix at end of this article for Election Information Bulletin from the Florida Secretary of State, the forms required by this law, and the instructions to candidates concerning use of the forms.

${ }^{8}$ The 1954 Democratic gubernatorial primary is not included because it was a special clection called to fill the vacancy created by the death of Governor Dan McCarty. 
TABLE I

Democratic Gubernatorial Primary Cost-per-Vote

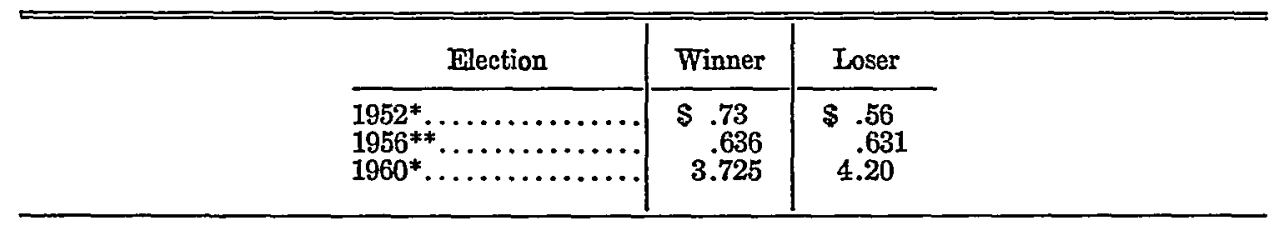

* First and Second Primary.

* Ono primary only required.

tributors increased only 5.8 per cent in this same period (I7,534 in 1952 to 18,445 in I960). Actually the per cent of registered Democratic voters who made contributions has remained less than two per cent in each of the races reported under the new law. In any event, Florida candidates have been able to collect sufficient funds with which to wage vigorous campaigns. Table two below indicates that while the candidate who has the greatest amount of money available to wage the campaign has the best chance of winning the election, there seems to be no correlation between the amount available and the order of finish for the remaining candidates.

Certainly, the "Who Gave It-Who Got It" law has made available much valuable information on money in elections. How did this law develop? What factors caused Florida legislators to pass this kind of legislation?

The first effort by Florida to regulate money in elections was an act passed by the legislature in 1897 which prohibited corporations from using money for political purposes. ${ }^{4}$ This early view of the legislators that money should come from individuals, not corporations, persists, and has been continued in the Election Code. ${ }^{.}$

TABLE II

Democratic Gubernatorial Primary

Total Contributions* of Leading Candidates

\begin{tabular}{|c|c|c|c|c|}
\hline Election & Order of Finish & Candidates & Contributions & Totals \\
\hline 1952 & $\begin{array}{l}\text { First } \\
\text { Third } \\
\text { Second }\end{array}$ & $\begin{array}{l}\text { Dan McCarty } \\
\text { Alto Adams } \\
\text { Brailey Odham }\end{array}$ & $\begin{array}{r}\$ 159,171.00 \\
141,734.00 \\
103,749.00\end{array}$ & $\$ 404,654.00$ \\
\hline 1956 & $\begin{array}{l}\text { First } \\
\text { Fourth } \\
\text { Second } \\
\text { Third }\end{array}$ & $\begin{array}{l}\text { LeRoy Collins } \\
\text { Fuller Warren } \\
\text { Sumter Lowry } \\
\text { Farris Bryant }\end{array}$ & $\begin{array}{r}299,165.00 \\
198,747.00 \\
117,002.00 \\
62,330.00\end{array}$ & $677,245.00$ \\
\hline \multirow[t]{2}{*}{1960} & \multirow[t]{2}{*}{$\begin{array}{l}\text { First } \\
\text { Second } \\
\text { Fourth } \\
\text { Fifth } \\
\text { Third } \\
\text { Sixth }\end{array}$} & \multirow[t]{2}{*}{$\begin{array}{l}\text { Farris Bryant } \\
\text { Doyle Carlton } \\
\text { John MeCarty } \\
\text { Fred Dickinson } \\
\text { Haydon Burns } \\
\text { Thomas E. David }\end{array}$} & \multirow[t]{2}{*}{$\begin{array}{l}784,898.00 \\
725,842.00 \\
218,449.00 \\
177,501.00 \\
173,471.00 \\
126,365.00\end{array}$} & $2,206,526.00$ \\
\hline & & & & $\$ 3,288,425.00$ \\
\hline
\end{tabular}

* Cent figures dropped throughout.

'Fla. Laws $1897, \mathrm{ch} .4538$.

'Frs. Stat. ANN. $\$$ I04.09I (I96I). Since $195 \mathrm{I}$ there have been a number of incidents of candidates 
An attempt to limit the sums that could be spent in campaigns for state offices, a popular reform theme at the time, was made by Florida legislators in $1913{ }^{\circ} \mathrm{We}$ may assume that the limits placed on campaign spending were reasonable at that time, but compared to spending as reported under the present Florida law they seem utopian. Candidates for United States Senate and governor were limited to $\$ 4,000$, while candidates for state offices were limited to lesser amounts and candidates for county offices in the smaller counties were limited to as little as $\$ 400$. These limits on expenditures were revised upward in 1927, giving both United States Senate and governor candidates a limit of $\$ 15,000$ which remained in effect until repealed in $1949 .^{7}$

By I949, legislators as well as the general public realized that the placing of limits on campaign expenditures had no discernible impact on money actually spent by candidates. The legislature in that year attempted, therefore, to make a more realistic law by'removing all limits on expenditures, but requiring that candidates report all of their expenses. This law was tested in a heated campaign for United States Senate in I950. The reports of each of the two Democratic contenders showed that he spent less than $\$ 100,000$, but the general view was that more than $\$ 500,000$ was actually spent in each instance..$^{8}$

By this time, Florida's legislators were convinced that (a) limits did not work and (b) that the 1949 effort had not succeeded. They were also painfully aware of some unsavory disclosures made before the Kefauver Committee at Miami and Tampa with regard to money in elections and were determined to try to block mass use of money from gambling interests. The public had also become aware of tie-ins between gangsters and some politicians under the old laws regulating money in elections and demanded legislative remedies." The old law had been honored more in the breach than in the observance. It was not at all unusual for a defeated candidate not to file a post-election financial report. He had lost anyway, and the penalty for failing to file was disqualification from holding office. It was time for a change.

Prior to the convening of the r95I Florida Legislature, one Florida newspaper, the St. Petersburg Times, carried on an educational campaign pointing toward

returning money given from corporation accounts and there is acceptance by political candidates that corporation contributions are not accepted. Corporation contributions were returned by Odham, McCarty, and Adams in 1952; by Collins, Odham, and Johns in 1954; by Collins and Bryant in 1956; and by Carlton, Bryant, and McCarty in 1960.

${ }^{\circ} \mathrm{Fla}$. Laws Igr3, ch. 6470.

${ }^{8}$ Charles O. Andrews, Jr., one of the authors of the new law, wrote that "the candidates for United States Senate in 1950 did not reflect in their reports anywhere near the amount of money that was expended in their behalf. The lavish use of newspaper advertisements and of radio broadcast time, and the other campaign expenses reflected an expenditure that could conservatively have been stated to exceed $\$ 600,000.00$ by each of the said candidates . . . ." Andrews, Regulation of Campaign Expenditures, 27 FLA. L.J. 15, 16 (1953).

"Public knowledge of these "tie-ins" came from the Kefauver hearings at Miami and Tampa and the reaction was one of indignation. Floridians had also been informed after the r949 legislative session that three men had each given the successful gubernatorial candidate in 1948 more than \$150,000.00 between the first and second primaries. One of the three was a Chicago and Florida race track owner and a long-time associate of the Capone Gang. 
the need to enact more realistic legislation on campaign finances. Each member of the legislature was given a copy of the articles written by a Times reporter, Morty Friedman, and was urged to enact new measures. Followers of Claude Pepper, who had been defeated in the bitter I950 senatorial campaign, also made a concerted effort to introduce measures which would place limits on total expenditures, so that a "poor man" would have a chance to make a race.

The legislators in 195 I were confronted with an aroused public advocating change in the Election Code with regard to money in elections. They all wanted a law that would keep the gangsters out of the money process. Some wanted to put limits back into the law so that a "poor man" could run, while others advocated no limits, but maximum publicity of all aspects of campaign financing. It was from these three forces that measures were shaped in both House and Senate which served as a basis for a final compromise bill (Senate Bill No. 8) drawn by a House-Senate Conference Committee and given the title the Dayton-Andrews bill. ${ }^{10}$ This conference committee bill established the mandatory requirement that all candidates make known to the public where their funds came from and for what purposes such funds were spent. Senate Bill No. 8 passed the House by a vote of 49-30 and the Senate 30-6, after having been defeated on a voice vote, and was then signed into law by Governor Warren.

The 195I Florida Revised Election Code is an effort to adjust state regulation of campaign finances to the realities of current politics. ${ }^{11}$ The law recognizes the impossibility of enforcing limits on total expenditures for public office, but demands complete publicity of all expenditures and all contributions, including services in lieu of cash contributions. ${ }^{12}$ Although it permits unlimited expenditures, it imposes a limit of $\$ 1,000$ on individual contributions. ${ }^{13}$ The doctrine of agency is incorporated into the law, by creating a Campaign Treasurer to whom all money or things of value go and by whom all expenditures are made. ${ }^{14}$ Thus the treasurer centralizes the money process in campaigns and makes possible an accounting of the flow of contributions and expenditures. The law also requires a type of reporting which makes it possible for the citizen to have an up-to-date account of all monies involved in a political race before he votes. ${ }^{15}$

Striking at funds from suspect sources, the legislators also prohibited "any contribution of any nature to any political party or to any candidate (candidates for municipal office are not subject to the revised law) for nomination for, or election to, political office in the state, 116 by:

I. those persons holding a horse or dog racing permit or any persons with a vested economic interest in horse or dog racing;

${ }^{10}$ The Conference Committee was composed of Senators W. A. Shands of Gainesville, Henry S. Baynard of St. Petersburg, and R. B. Gautier, Jr., of Miami, and Representatives Perry E. Murray of Frostproof, Richard H. Simpson of Monticello, and Woodrow Melvin of Milton.

${ }^{11}$ FIA. StAT. ANN. \$99.16r (1960). ${ }^{12} I d . \$ 99 . x 6 \mathrm{I}(4)(\mathrm{a})(7)$.

2s Id. $\$ 99.16 \mathrm{r}(2)$.

10 Id. $599.16 \mathrm{r}(7)$.

${ }^{14}$ Id. $\$ 99.16 \mathrm{I}(\mathrm{I})(\mathrm{a}),(\mathrm{b}),(\mathrm{c}),(3),(4),(7)$.

${ }^{10} \mathrm{Id}$. $\$ 99.16 \mathrm{I}(\mathrm{xo}), 99.16 \mathrm{r}(\mathrm{x})(\mathrm{a}),(\mathrm{b}),(\mathrm{c})$. 
2. those persons holding a license for the sale of intoxicating beverages or any persons with a vested economic interest in same; and,

3. persons operating a public utility subject to grant of franchise or regulation by the state or any persons with a vested economic interest in same; however, persons who are members of non-profit cooperative corporations operating public utilities are exempt from this prohibition.

The law also prohibits last-minute and post-election contributions as well as campaign indebtedness. ${ }^{17}$ These provisions were aimed at preventing a candidate in the closing drive from making commitments in return for financial aid. Recognizing the impossibility of filing a complete report of all monies in a campaign before the election, the law requires a final cleanup report for all contributions and all expenditures fifteen days after the election. ${ }^{18}$ However, in each campaign to date, more than ninety-five per cent of the total contributions and expenditures has been reported prior to the election.

Although the 195I legislative session left doubt as to how the law would be enforced, the 1955 session clarified this point to a marked extent. Now, any elector who believes that the election code has been violated may file a petition with the circuit court in the county in which the persons charged resides. As soon as the Attorney General receives a copy of the petition, he acts as counsel for the state and files such pleadings in the proceeding as he determines ought to be filed. ${ }^{10}$ Also, the 1955 session made it possible for any elector to file a complaint with the appropriate state agency and, if the finding of fact is that the person violated section $99 . \pi 6 \mathrm{I}(3),(4),(5)$, or (6), then the charter, permit, license, or franchise of the defendant person, persons, corporation, or utility will be revoked. ${ }^{20}$

The punitive section of this revised code was sufficiently serious to cause the Attorney General, in an opinion of September 25, 1951, to warn candidates,

The penalty provisions of its [the new election campaign expense law] violation, as set forth in section 104.27, are so drastic in relation to a person's candidacy that, in the absence of court construction, extreme caution should be observed in arriving at the meaning and intent of its provisions.

These penalties range from the possibility of conviction for commission of a misdemeanor or felony, citation for contempt, revocation of charter, permit, license or franchise, to loss of commissions to office.

The Capital Press Corps does a thorough job of studying the Campaign Treasurer's pre-election report, sending stories each week to their home newspapers highlighting local donors. Former Secretary of State R. A. Gray told a special House Committee investigating I952 campaign expenditures,

I do not wish to exaggerate, but I frequently had to shove reporters out of the way before I could get the papers [Campaign Treasurer's Pre-Election Report] filed ...

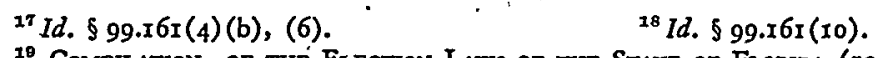

19 Compilation of the Election Laws of the State of Flordda (r96I).

${ }^{20}$ Fis. Stat. ANn. $\$$ I04.27(10) (1960). 
because they [reporters] would grab them just as soon as they came in. I had to plead with them to let me open the mail of the candidates, as they all stood around to get the figures. There was splendid publicity. . . .

Capital reporters continue to give the Florida voter full coverage of the "Who Gave It-Who Got It" section of the Election Code.

The campaign treasurers' reports have been made readily available to the public, and the Elections and Commissions Division of the Secretary of State's office has cooperated fully with all citizens who wish to examine them. Twice the Florida State University Research Council granted the writer financial assistance for detailed examination of these reports. These grants permitted full-time research during the summers of $195^{8}$ and 1960 . The donor lists for 1952 , I954, I956, and. I960 gave the name, address, and the sum contributed in each of these campaigns. Working from this base, we checked business and professional directories, telephone directories, and municipal and county directories in order to make a more complete identification of the donors. The newspaper reports have also been helpful in enlarging our knowledge of the identity of donors. Furthermore, we have carried out extensive interviews and have had correspondence with a number of donors, in attempting to learn more about who gives money in Florida political campaigns.

Our research indicates that more than sixty per cent of the donors were past their fortieth birthday, with approximately eighty per cent being between their thirtieth and fifty-sixth birthdays.

Although the donor lists report that money has been contributed in sums of fifty cents to $\$ \mathrm{I}, 000$, and that virtually every segment of Florida society has made some financial contribution, lawyers dominate the lists, especially in the sums given. Individuals who sell real estate, insurance, and bonds rank next. Road contractors and builders follow closely with medical doctors, merchants, bankers, citrus growers, and motel-hotel owners grouped in descending order. Public officials and farmers stand at the bottom of the list of those who give substantial sums of money.

Another characteristic of the Florida donor is that he is a repeater. The donor lists show that many of the $17,000-18,000$ donors have given money in a number of campaigns. Our findings are that more than sixty per cent had given more than four times, seven per cent four times, eleven per cent three times, and thirteen per cent twice in the I952-rg60 period.

We were especially interested in learning why these people gave money. Some said they gave money because they believed their candidate would do the best job; some because the candidate was a close friend or relative; and some because the candidate pushed an issue or issues with which they agreed. A few donors admitted quite frankly that they gave money just as they invested funds in a corporate enterprise. They gave the money and they anticipated a return on their investment. Other donors reported that they sought social position-special invitations from the governor to social events, or a chance to entertain the governor in their own home. Some were seeking a more favorable position for their business; 
and others were interested in gaining political prestige by being local contact person for the successful candidate.

Information obtained from interviews indicates that some persons are opposed to being identified on the public reports as donors. (On the other hand, some give money and their names appear on the public reports, although in reality they are supporting a different candidatel) Some who object to being identified publicly insist that this is a private matter; others fear economic reprisal; and still others fear their support would affect their candidate adversely. In view of our findings, it would seem that there will always be a few individuals whose donations will not be publicly known. However, the overwhelming consensus is that the Florida law has reduced this number to a bare minimum.

The reports themselves show that the greatest amount of money came from the commercial and financial centers of the state. Dade, Duval, Pinellas, Hillsborough, Orange, Broward, Polk, Leon, and Escambia counties lead the list of counties with the largest sums of money reported as well as the largest number of donors. Certain cities dominated the donor lists: Miami and Miami Beach, Fort Lauderdale, Jacksonville, Tampa, Fort Pierce, Ocala, St. Petersburg, Tallahassee, Orlando, West Palm Beach, Pensacola, Lakeland, and Panama City.

Most of the money in recent campaigns has come from donations in the above $\$ 250$ category. In 1952 there were twenty-nine $\$ 1,000$ donations recorded; but in I 960 there was an increase to 360 such donations. At the other end of the scale$\$ 50$ or less-there were 14,330 such donations for three candidates in $195^{2}$ but only I0,7x 8 in 1960 for six candidates, a decrease of twenty-five per cent. The reports also indicate that candidates prefer to list as few $\$ 1,000$ contributions in one sum as possible. They have been listing them by $\$ 100$ or $\$ 250$ units over the weeks and in a few instances by two entries of $\$ 500$ each. This listing might also indicate that the candidate has received an oral pledge of the $\$ I, 000$, but he calls the money at the rate he deems best suited to the campaign. The reports show that all candidates have tended to submerge the $\$ \mathrm{r}, 000$ donor by listing his total donation in lesser amounts in several weekly reports.

TABLE III

Size of Contributions Reported by Democratic Gubernatorial Candidates1952 AND 1960

\begin{tabular}{|c|c|c|c|c|c|c|}
\hline \multirow{2}{*}{ Contributions } & 1952 & 1960 & 1952 & 1960 & 1952 & 1960 \\
\hline & D. McCarty & Bryant & Odham & Carlton & Adams & Burns \\
\hline $\begin{array}{l}\$ 1000 \ldots \ldots \ldots \ldots \\
\$ 500 \$ 999 \ldots \ldots \\
\$ 251-\$ 499 \ldots \ldots \\
\$ 101 \$ 250 \ldots \ldots \\
\$ 51 \$ 100 \ldots \ldots \\
\$ 50 \text { and under... }\end{array}$ & $\begin{array}{r}6 \\
42 \\
71 \\
916 \\
901 \\
2,876\end{array}$ & $\begin{array}{r}123 \\
93 \\
600 \\
667 \\
983 \\
3,781\end{array}$ & $\begin{array}{r}4 \\
2 \\
54 \\
390 \\
167 \\
11,086\end{array}$ & $\begin{array}{r}84 \\
44 \\
496 \\
795 \\
1,017 \\
3,988\end{array}$ & $\begin{array}{r}19 \\
61 \\
103 \\
322 \\
86 \\
368\end{array}$ & $\begin{array}{r}30 \\
4 \\
99 \\
182 \\
195 \\
628\end{array}$ \\
\hline
\end{tabular}


Table three compares the size of individual contributions in the first campaign under the law and the most recent campaign.

We are concerned not only with who gives money and the size of the candidate's campaign fund but also with how he spends his money. The reports of expenditures for $1952-1960$ tell us the types of spending by the candidates.

In the 1952 primary, the first gubernatorial campaign under the "Who Gave ItWho Got It" law, there were three leading Democratic candidates; and a runoff primary was necessary. The total expenditures for both primaries for these candidates were $\$ 404,654$. In the special gubernatorial race of I954 there were three leading Democratic candidates and two primaries with a total expenditure of $\$ 741,000$. In I956 there were four leading Democratic candidates but only one primary, as Collins won nomination in an unprecedented first primary. The total expenditures in that one primary were $\$ 677,245$. In the hotly contested Democratic gubernatorial primaries of 1960 the reported expenditures reached a new high of $\$ 2,118,655$ by the top six candidates in two primaries.

These spending reports verify what we have observed-namely, candidates intensify their efforts as they near the election date. The leading candidates without exception markedly increased their rate of spending during the three weeks prior to the first primary and the reports show the sharpest rise in the final week. 'The pattern for the rate of spending in $195^{6}$ is characteristic of the four campaigns under the new law: the winner reported sixty-two per cent of his total expenditures during the final three weeks period, the runner-up forty-nine per cent, the third candidate fifty-one per cent, and the fourth fifty-eight per cent of the total, and in each case the greatest expenditures were reported in the final week.

The 1956 contest for governor reflects campaign expenditures typical of the other three races we have investigated. In that race Collins, the winner, devoted the greatest portion of his campaign funds to television, printing, newspaper and radio advertising. He made major use of television and was the first Democratic gubernatorial candidate to commit such a large share of his fund to this type of appeal. He also used printed literature, much of which was hand-carried to voters rather than mailed. Lowry, the runner-up, made major use of mailed literature. Bryant, the third man and the candidate who ran again, and successfully, in Ig6o, reported in the midst of his campaign that he was having a difficult time collecting funds with which to wage the kind of campaign he thought necessary to win. (Bryant apparently did not have this problem during his Ig60 race as he reported collecting $\$ 836,185$ in contrast to the $\$ 62,330$ in 1956.) Bryant's type and rate of spending was, therefore, a reflection of what he considered an insufficient campaign exchequer and his I960 spending pattern altered somewhat the 1956 pattern. In $195^{6}$ he relied on television, printing, travel, and newspapers in that order, while in 1960 he utilized television, printing, radio, and newspapers. Warren, the fourth man in the race, used newspapers, paid workers, television and radio as his chief 
TABLE IV

Top Eleven Expenditures

Democratic Candidates-I956

\begin{tabular}{|c|c|c|c|}
\hline Collins & Lowry & Bryant & Warren \\
\hline $\begin{array}{l}\text { 1. Television } \\
\text { 2. Printing } \\
\text { 3. Newspapers } \\
\text { 4. Radio } \\
\text { 5. Paid Workers } \\
\text { 6. Mailing and Distri- } \\
\text { bution of Literature } \\
\text { 7. Rent } \\
\text { 8. Banners and Bill- } \\
\text { boards } \\
\text { 9. Bumper Strips } \\
\text { 10. Travel } \\
\text { 11. Telephone }\end{array}$ & $\begin{array}{l}\text { 1. Mailing and Distri- } \\
\text { bution of Literature } \\
\text { 2. Paid Workers } \\
\text { 3. Television } \\
\text { 4. Printing } \\
\text { 5. Newspapers } \\
\text { 6. Travel } \\
\text { 7. Radio } \\
\text { 8. Rent } \\
\text { 9. Telephone } \\
\text { 10. Bumper Strips } \\
\text { 11. Banners and Bill- } \\
\text { boards }\end{array}$ & $\begin{array}{l}\text { 1. Television } \\
\text { 2. Printing } \\
\text { 3. Travel } \\
\text { 4. Newspapers } \\
\text { 5. Radio } \\
\text { 6. Paid Workers } \\
\text { 7. Telephone } \\
\text { 8. Rent } \\
\text { 9. Mailing and Distri- } \\
\text { 10. Bution of Literature } \\
\text { 11. Bunners and Bill- } \\
\text { 11. Bumper Strips }\end{array}$ & $\begin{array}{l}\text { 1. Newspapora } \\
\text { 2. Paid Workors } \\
\text { 3. Television } \\
\text { 4. Radio } \\
\text { 5. Printing } \\
\text { 6. Rent } \\
\text { 7. Travel } \\
\text { 8. Telephone } \\
\text { 9. Banners and Bill- } \\
\text { boards } \\
\text { 10. Bumper Strips } \\
\text { 11. Mailing and Distri- } \\
\text { bution of Literature }\end{array}$ \\
\hline
\end{tabular}

types of expenditures. Table four ranks in descending order the top eleven expenditures in 1956 .

A composite rating of the leading types of expenditures in $195^{6}$ places the top five as follows: television, printing, newspapers, radio, and paid workers, in descending order of importance. In I 960 , for the first time the four leading candidates made use of professional public relations firms, ${ }^{21}$ whose practice it was to lump types of expenditures together. ${ }^{22}$ Preliminary examination of the reports indicates that campaign spending in this race still followed closely the 1956 pattern.

Because of the great distances between metropolitan centers in Florida, candidates make major use of airplanes. Governor Collins used a chartered airplane in his successful I956 contest, carrying with him a newspaper man, a television-radio advisor, and one or two confidential assistants. Governor Bryant, who is a pilot, not only flew throughout the state during his victorious Ig6o campaign, but has carried his enthusiasm for air travel into office, and the state of Florida now owns a fleet of aircraft.

An interesting and understandable consequence of the law is the use of a certified public accountant as the Campaign Treasurer. Although only one C.P.A. was used as a treasurer in the first campaign under the new law, in I960 five of the six leading candidates made use of a C.P.A. as their Campaign Treasurer. ${ }^{23}$ Now not only a majority of the treasurers, but even most of the deputy treasurers are certified public accountants.

\footnotetext{
21 The public relations firms used in rg60 were: Bryant: Louis Benito Advertising of Tampa, and Venn-Cole and Associates of Miami; Carlton: Bishopric-Green-Fieldin, Inc., of Miami; Burns: Miller, Bacon, Avrutus \& Simons, Inc., of Jacksonville; McCarty: Newman, Lynde \& Associates of Jacksonville; and Dickinson: Coryell \& Associates of Jacksonville.

${ }^{22}$ Typical lumped expenditures reported were: "radio-TV-newspaper," "advertising," "public relations," "TV-radio," "TV-newspaper-radio," "billboards and newspaper," "TV-advertising," "advertising and publicity," and "billboards and TV."

${ }^{23}$ Bryant: James S. Weaver; Cariton: Russell S. Bogue; Burns: George W. Dandelake (also a lawycr); McCarty: James S. Keller, Jr.; and Dickinson: William A. Stockton.
} 
Another development has been a reduction in the number of candidates running in the primary. In the four Democratic gubernatorial primaries prior to the passage of the new law, there were forty-two candidates; yet, since the law we have had only twenty-four candidates in four elections. The wide publicity given to the high cost of campaigning almost certainly has had a bearing on the reduction of the number of candidates.

Before this law was enacted, it was customary for candidates to gain pledges of financial support before making a public announcement or filing qualifying papers. This was done quietly, and was not known by the general public. After all, with a limit of $\$ 15,000$ on total expenditures, how could the public know the sums of money necessary to make a statewide race? After this law has been in operation for four gubernatorial races, Floridians have a good idea of the high cost of running such a contest. The gathering of pledges of financial support has become more widely known. The identity of certain individuals as "money raisers" (campaign finance chairmen), as well as the sources of financial support is a matter of public knowledge. Potential candidates do not have to "play by ear," as they did formerly, because they know they must plan long in advance, obtain their pledges of financial support, and make use of various propaganda facilities if they hope to wage a successful campaign.

Table five shows the increase in the cost of state-wide campaigning since 1952 . Some contend that the extremely sharp jump between the $1956-60$ races resulted from a hard-fought contest between six candidates. Others believe that the rise resulted from the entry of professional public relations firms for the four leading candidates. Perhaps both were contributing factors to the increase, along with the general inflationary spiral which is affecting our economy.

The Attorney-General has been asked many questions concerning the meaning of the "Who Gave It-Who Got It" law. His office has consistently viewed the law as a legitimate effort under the police power of the state to regulate money in elections, and has attempted at every opportunity to insure that all monies or things of value go to and through the Campaign Treasurer. When required to take cases

\section{TABLE V}

Democratic Gubernatorial Primaries

I952, $1954, x 956$, x 960

\begin{tabular}{|c|c|c|c|}
\hline Primary & $\begin{array}{l}\text { Number of } \\
\text { Candidates }\end{array}$ & Total Contributions & Total Expenditures \\
\hline $\begin{array}{l}1952^{*} \ldots \ldots \ldots \ldots \ldots \\
1954^{*} \ldots \ldots \ldots \ldots \ldots \ldots \\
1956^{* *} \ldots \ldots \ldots \ldots \ldots \ldots \\
1960^{*} \ldots \ldots \ldots \ldots \ldots\end{array}$ & $\begin{array}{r}5 \\
3 \\
6 \\
10\end{array}$ & $\begin{array}{r}563,730.00 \\
741,000.00 \\
677,245.00 \\
2,223,297.00\end{array}$ & $\begin{array}{r}.563,730.00 \\
741,000.00 \\
677,245.00 \\
2,138,307.00\end{array}$ \\
\hline 4 & 24 & $\$ 4,205,272.00$ & $\$ 4,120,282.00$ \\
\hline
\end{tabular}

* Tro primaries.

* Ono primary only. 
to the courts, the attorneys from his office have made persuasive presentations, and in all cases except one ${ }^{24}$ the majority of the Florida Supreme Court or the judge of the circuit court has sustained the position of the Attorney-General.

The first serious challenge in the courts was initiated in 1952 by the editor of the Calhoun County Record of Blountstown, who brought suit in behalf of many Florida weekly newspapers contending that the law restrained him in his free right to publish a newspaper and was therefore a violation of the constitutionally guaranteed freedom of the press. Circuit Judge Ira A. Hutchison of Panama City upheld his contention. In the meantime, the owner of radio station WPLA at Plant City brought suit contesting the constitutionality of the law on the grounds that it violated both freedom of press and freedom of speech. In this case, Circuit Judge Henry Tillman of Tampa held that the law did not violate either guarantee.

A Tallahassee attorney, Kenneth Ballinger, arguing both cases, contended that the constitutional rights of his clients were abridged by provisions of the Election Code which required all advertising and radio time purchases to be cleared through a candidate's Campaign Treasurer. He said that such a requirement is an "unconstitutional restraint" on the citizen who wants to buy advertising in behalf of a candidate or speak over the radio for his favorite nominee. He further argued that, since the law would not permit a newspaper owner to mail out extra copies of papers containing an editorial favoring a candidate, print or distribute handbills, hire a hall, rent sound equipment, or "take advantage of the mechanical aids of free speech," without prior authorization from the candidate or his representative, this provision of the law amounted to previous license and censorship, both unconstitutional.

The attorneys for the state denied that the law prohibited any citizen from purchasing radio or newspaper advertising space, contending that it merely required that they do so through the authorized agent of the candidate, the Campaign Treasurer. They pointed out that there was no "inherent right" of a citizen to buy radio time or newspaper space and that the right of a publisher or broadcaster to reject advertising or talking time had been sustained in the courts. The most significant part of their brief was their insistence that to strike down this section of the new law would defeat the intent of the legislators and make it impossible for Florida citizens to learn "who gave it and who got it." The court held on March I7, I953, by a vote of four to two, that the $195 \mathrm{I}$ law requiring all campaign expendi-

${ }^{24}$ The exception was a case questioning when an individual becomes a "candidate," and, therefore, required to file weekly contributions and expenditures reports. The Florida Supreme Court held that under the law "candidacy" resulted either when a person (a) made a public announcement of his candidacy, or (b) filed for an elective office. This case was brought to the attention of the court after friends of one 1956 gubernatorial candidate (Fuller Warren, a former governor) ran newspaper advertisements stating "Let's return Fuller to Tallahassee." Since Warren had neither announced publicly nor filed for the office of governor, no report was filed with the Secretary of State. The Attorncy-General's office argued that this advertisement constituted an announcement of candidacy and therefore section 99.I6I applied. The Supreme Court upheld the view of the friends of Mr. Warren. Some observers believe, however, that even though the Warren supporters won this case, they created unfavorable publicity for their candidate, who finished fourth in the 1956 race. Ervin v. Capital Weekly Post, Inc., and P. O. Riley, 97 So.2d $46_{4}$ (Fla. Sup. Ct. I957). 
tures to clear through a candidate's treasurer and to be strictly accounted for was a constitutional exercise of the police power of the state. ${ }^{25}$

The leading case on the consequences of failing to file the required reports was that of Evans v. Carroll, decided July $16,195^{8.26}$ In this case a candidate who was elected to the office of constable in the 1956 election had simply ignored the requirement for filing contributions reports and the judge of the circuit court of that county (Palm Beach) found as a fact that the constable-elect had willfully or knowingly violated the law, whereupon the judge decreed his election to be void and the office vacant under the provisions of section $104.27(2)$ and (9). The circuit judge's decision was appealed to the second district court of appeal at Lakeland, which sustained his decision; and the Florida Supreme Court held that there was no basis for an appeal to that court.

The Florida effort to regulate money in elections has been successful if measured by any objective standard. The Florida voter knows more than he has ever known concerning money in Florida elections. Candidates in Florida have come to realize the financial requirements of campaigning as never before. Both voter and candidate are painfully aware of the high cost of running for office. Although efforts have been made to break through to new ground in reducing the high cost of campaigning, no legislation has been passed which accomplishes this goal. Florida legislators were persuaded to reduce the campaign period; but, after one shortened campaign (candidates spent the money faster) with increased expenditures, the law was repealed and campaigns reverted back to the February to November period.

There are, however, some suggestions for modifications of the present law. First, it has been urged that Florida establish an Elections Commission comprised of the Attorney-General, the Secretary of State, and the Chief Justice of the Supreme Court, and that this Commission would employ an executive director, whose responsibility would be to give maximum publicity to all reports and to insure an even higher degree of compliance with the law. Second, it has been recommended that each contributor of $\$$ roo or more sign a contribution slip certifying that the money contributed is his own. Third, require the complete address of each donor. Fourth, tighten section 99.17 with regard to "things of value." Fifth, make use of a publicity pamphlet. Sixth, encourage local radio and television stations to donate free time to candidates. Seventh, eliminate the limit of $\$ I, 000$ for individual donors. Eighth, require each candidate, at the time of filing, to submit a confidential statement of his financial condition at that time, and then require the elected official to file a similar statement each year that he holds public office.

Florida authorities report no difficulties as to the workability of the reporting requirements of the law. Former Secretary of State, R. A. Gray, has commented publicly that the reporting provisions have worked very well. The present Secretary of State, Tom Adams, has written: "I do not feel that this provision [reporting]

\footnotetext{
${ }^{28}$ Smith v. Ervin, 64 So.2d I66 (Fla. Sup. Ct. I953) and Finlay v. Ervin, I Fla. Supp. I98 (Calhoun County r952).

${ }^{20}$ 108 So.2d 782 (Fla. Dist. Ct., 2d Dist. 1959).
} 
of the law is too cumbersome or expensive for a candidate to comply with." ${ }^{27}$ The Attorney-General, Richard W. Ervin, agrees with both Secretary of State Adams and former Secretary of State Gray that the reporting provision requirement is not cumbersome nor too expensive for candidates and has asserted that he knew of no major candidate who has complained concerning the reporting provisions.

The National Municipal League conducted its own investigation of the Florida law and found that the law was in full operation in the Secretary of State's office as well as that of the Attorney-General, that no difficulty had been found in securing reports from all candidates, and that pre-election reports were alertly scrutinized by rival candidates and the press in time for influence on the voters. They then based their model state campaign contributions and expenditures reporting law on the Florida "Who Gave It-Who Got It" law..$^{28}$

In view of the decisions handed down by Florida courts, the opinions of the Attorney-General, the views of the Secretary of State, and various strengthenings of the law by subsequent legislative enactments, Floridians have demonstrated their support of this new approach to effective regulation of campaign finances. Former Secretary of State R. A. Gray has stated that "The general opinion is that they [reporting requirements] should remain, that they had worked well, that it brought into the open the amounts contributed, the sources of contributions, and the amounts expended, and the purposes for which expended," and he added that he thought a similar plan "would be very wholesome for national elections." ${ }^{29}$ Attorney-General Ervin says that the law is working well. Secretary of State Tom Adams, the chief administering officer for the law, only recently wrote to me stating, "I feel that this [reporting] gives the voter a better knowledge about what is being spent and from what sources the money is obtained than anything we have had."30

Once, that old adage "If you can say it, don't write it; if you can nod it, don't say it; if you can wink it, don't nod it," applied to the money process in Florida campaigns. Now the "Who Gave It-Who Got It" law has made public property of one of the most vital elements in competitive democratic politics-money in campaigns.

\section{ADDENDUM}

Almost immediately following the preparation of this article, President Kennedy's Commission on Campaign Costs ${ }^{1}$ issued its report. ${ }^{2}$ The bipartisan Commission was

${ }^{27}$ Letter from Tom Adams to Elston Roady, Feb. 9, I962.

28 National Municipal League, Model State Campaign Contributions and Expenditures ReportING LAw (Fourth Draft, I96I).

${ }^{20}$ Testimony before the House Special Committee to Investigate Campaign Expenditures, p. I72 (1952). President Kennedy's Commission on Campaign Costs, in its report published in April r962, urges greater publicity concerning money in national elections. See President's Comm's on Caspason Costs, Financing Presidential Campaigns, Report i6-i7 (Ig62).

${ }^{30}$ Letter from Tom Adams to Elston Roady, Feb. 9, 1962.

\footnotetext{
- ${ }^{1}$ Members of the Commission were:

Alexander HeArd, Chairman, Dean of the Graduate School, University of North Carolina, author, TuBs COSTS OF DEMOCRACY (I960).

V. O. KEY, JR., Professor of Government, Harvard University; author of various books on American politics.
} 
headed by Dean Alexander Heard of the University of North Carolina, a leading authority on campaign finance. The Commission held a total of eleven days of meetings, and subcommittees met at numerous other times. They solicited suggestions from more than 700 persons, consulted former Presidents and Vice Presidents, as well as former candidates for those offices, obtained important information and counsel from various governmental agencies, examined the many reports of both House and Senate relating to campaign finance. They also studied reports of government financing of campaigns in the Commonwealth of Puerto Rico (and two members and the Executive Director spent three days visiting there), and they inquired as to how other democratic nations attempt to solve problems of campaign finance. Although representing both major parties, various sections of the nations, and a variety of views on the question of campaign finance, the Commission concurred unanimously in the twelve recommendations submitted to President Kennedy on April r8, rg62.

President Kennedy, on May 29, I962, submitted to Congress proposed legislation implementing the Commisson's recommendations. ${ }^{3}$ The first item in both the Commission's and President Kennedy's proposal to Congress was a tax incentive to campaign donors in hopes of reducing the dependence upon large donations by a few. To encourage small donors, both proposed a tax credit against federal income tax for fifty per cent of a contribution up to \$Io a year for an individual, or $\$ 20$ on a joint return of husband and wife. This would mean that a person owing $\$ 250$ in income tax and contributing \$20 to a political party would pay a tax of \$240. The President also advocated that large donors be given tax relief by permitting a tax deduction for political contributions up to a maximum of $\$ 750$ a year. (The Heard Commission had recommended $\$ r, 000$.) If this proposal were adopted, a

DaN A. Kumbarl, President, Aerojet-General Corporation; Secretary of the Navy, I95I-52; Chairman, Los Angeles Host Committee for r960 Democratic National Convention; Chairman, Southern California Democratic Committee for Kennedy-Johnson, 1960.

Malcolm C. Moos, Adviser to the Rockefeller Brothers on Public Affairs; Professor of Political Science, The Johns Hopkins University; Administrative Assistant to President Eisenhower, I958-6I; Chairman, Republican State Central Committee of Baltimore, I954-58.

Paul A. Porter, partner, Arnold, Fortas \& Porter; Chairman, Federal Communications Commission, 194446; Director of Campaign Publicity, Democratic National Committee, I944.

Neil O. Staenzer, Democratic National Committeeman from Michigan; Chairman, Michigan Democratic State Central Committec, I950-6r; Chairman, Democratic National Advisory Committee on Political Organization, 1955-60.

Walter N. Thayer, President, New York Herald-Tribune; member, Finance Committee, Citizens for Eisenhower-Nixon, 1952; member, United Republican Finance Committee of New York, 1954-60, Treasurer, 1958-60; National Finance Chairman, Volunteers for Nixon-Lodge, I960.

Joun M. Vonxs, partner, Vorys, Sater, Seymour \& Pease; member, U.S. House of Represèntatives, 1939-59; Ohio member, National Republican Congressional Committee, I949-54.

JAMEs C. Wormay, partner, Cresap, McCormick \& Paget; Assistant Secretary of Commerce, 1953-55; President, United Republican Fund of Illinois, 1959-60; President, Republican Citizens League of Illinois, 1961-62; member, Republican National Finance Committee, 1959-.

The Executive Director was Herbert E. Alexander, and the Assistant Director was Irvin Iechliter. 2 President's Commission on Campaign Costs, Financing Presidential Campaigns (ig62).

${ }^{3} 108$ Cong. Rec. 8755 (daily ed. May 29, I962). The President's proposed legislation relating to election of President and Vice President was laid before the Senate by the President pro tempore and was then referred to the Committee on Rules and Administration. 
taxpayer earning $\$ 20,000$ a year and contributing $\$ 500$ in a presidential campaign would get a net tax reduction of just over \$roo. In both instances, the contribution would have to be made either to the national committee of a political party or to a state committee designated by the national committee. President Kennedy sent letters to both Vice President Johnson and Speaker John W. McCormack suggesting that the Congress might wish to consider extending the tax incentives to campaigns other than the presidential race. ${ }^{4}$ The President summed up the argument for a broader financial base in political campaigns by asserting: "In these days when the public interest demands basic decisions so essential to our security and survival, public policy should enable presidential candidates to free themselves of dependency on large contributions of those with special interests." These tax incentive proposals as a spur to political contributions received the endorsement of the chairmen of the Democratic and Republican National Committees, former Presidents Harry S. Truman and Dwight D. Eisenhower and three former presidential candidates, Thomas E. Dewey, Adlai E. Stevenson, and Richard M. Nixon.

President Kennedy also accepted four other recommendations of the Heard Commission. First, he proposed the creation of a Registry of Election Finance in the General Accounting Office, which would receive periodic reports of contributions and expenditures in campaigns both for nomination and election from all candidates for President and Vice President. Any political committee raising or spending as much as $\$ 2,500$ for a party candidate would be required to file periodic reports with the Registry of Election Finance. Any individual or family contributing more than $\$ 5,000$ a year in the aggregate would also have to make reports. These reports would be made public. This follows closely the provision of the Florida law.

Second, the President called existing ceilings on committee expenditures and individual contributions "ineffective," and said that "existing practices violate the spirit, if not the letter of the law." He recommended repealing these limits but insisted on adequate public disclosure through the office of the Registry of Election Finance. While this provision is also similar to the Florida law, it goes a step further by removing limits on individual contributions.

Third, the President accepted the Commission's recommendation to request a temporary suspension of the "equal time" provision in the Federal Communications Act for presidential candidates; and fourth, he urged federal government financing of the costs of the transition from outgoing to incoming administrations.

Perhaps we have reached a climate of opinion on Capitol Hill receptive to these presidential proposals. However, it is sobering to note that able men have made many efforts to create more realistic federal regulation of campaign finances with little or no success. Certainly these proposals of President Kennedy have received a maximum bipartisan support and if the Majority and Minority leaders believe this is the time for such radical change in federal regulation of presidential campaigns, then

N.Y. Times, May 30, r962, p. I, col. 5, at p. I6, col. 2.

I 1 bid. 
we may expect legislative action. The President of the United States and leaders of both political parties have accepted these proposals of the Heard Commission and indicate that they ought to be given a chance. Whether congressional leaders share this attitude remains to be seen.

\section{APPENDIX \\ EXPLANATION OF FORMS ENCLOSED FOR USE IN CONNECTION WITH CANDIDACY FOR PUBLIC OFFICE}

Form A-5 Campaign Deposit Slips are to be used to make all deposits to your campaign accounts. This form is in triplicate. Two copies should be retained by the Depository and one copy for your files. All funds received in furtherance of the candidacy shall be deposited within 24 hours after receipt thereof. Accompanying all deposits shall be a detailed statement showing the names and addresses of the persons contributing and the amount. Section 99.161 (5) F.S.

Form A-6 Authorization of Campaign Expenditure, Certificate of Claimant and Order for Payment. These are all on one form. This form should be used to pay all expenditures in connection with candidacy. Parts 1 and 3 must be accomplished by the campaign treasurer or deputy campaign treasurers. The part 2 is accomplished by the claimant. Expenses shall not be authorized unless there are moneys on deposit in the campaign account sufficient to pay the amount of the expenses so authorized. Section 99.161 (6) (7) F.S.

Form A-7 Campaign Treasurer's Pre-election Report. These forms are required to be filed by the campaign treasurer with the Secretary of State as follows:

Governor and United States Senator-on Monday of each week preceding the Election.

All other offices-on the first Monday of each month preceding the Election.

Duplicate copy shall be filed by the same time with the Clerk of the Circuit Court of the County in which the candidate resides. Section 99.161 (8) F.S. 


\title{
ELECTION INFORMATION BULLETII
}

\author{
TOM ADAMS \\ SECRETARY OF STATE \\ TALLAHASSEE, FLORIDA
}

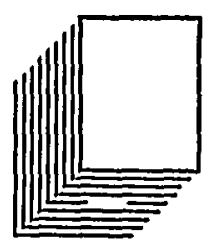

JULY 15, 1961

\section{INFORMATION FOR CANDIDATES}

The information given below is taken from Florida Election Code and also will be found in the Florida Statutes, Chapter 99.

1. Before or when the candidate qualifies, and as a condition precedent to qualifying, the law requires the candidate

a. To appoint one campaign treasurer

and file name and address of each with the officer before whom he qualifies (Ch. 99.161 Section 3)

2. a. The candidate may designate himself or any other elector as his campaign treasurer. The candidate may designato any bank lawfully operating in Florida as his campaign depository. Campaign Treasurers may appoint deputy treasurers and may designate not more than one depository in each county, but in cach ease the names and addresses of deputy treasurers and additional depositories must be filed with the offiecr before whom candidate is required by law to qualify. Vacancies when filled must be certified.

b. A person may announce his candidacy at any time he desires. Such announcement should be immediately followed, if not preceded, by the appointment of a campaign treasurer and the designation of a campaign depository. Thereafter the candidate may receive contributions for deposit in his campaign account and must make periodic teports as required by Section 99.161 (8) F.S.

\section{CONTRIBUTIONS}

1. All campaign contributions and all expenditures (or obligation to expend) must be made through the duly appointed campaign treasurer or deputy campaign treasurers. (Ch. 99.161 Section 4) (a)

2. Contributions are limited directly or indirectly in monies, materials, supplies or by way of loan not to exceed $\$ 1,000.00$ (Ch. 99.161 Sec 2)

3. Candidates are prohibited from contributing to charitable or eleemosynary organizations and such onganizations aro likewise prohibited from soliciting. (Ch. $99.161 \mathrm{Sec}$. 2)

4. No contribution may be received less than live days preceding the primary. (Ch. 99.161 Sec. 4) (b)

5. All contributions must be deposited in the designated depository within 24 bours (Sundays and holidays cxeepted.) Ch. 99.161 Sec. 5)

6. Deposit Slips or forms must be in triplicate (2 copies for the campaign depository and one to be retained by campaign treasurer) and shall show the name, address and amount contributed by each contributor. (Ch. 99.161 Søc. 5) (Scc. of State Form A-5)

\section{PROHIBITED CONTRIBUTIONS}

(Ch, $99.161 \mathrm{sec}, 1)$

1. No contribution shall be made directly or indirectly to any political party or to any candidate for nomination for or election to any political office in the State of Florida by any corporation or by:

2. Any person holding horse or dog racing permit.

b. Any Mernber of association holding such permit.

c. Any officer or director or supervisory employee of a corporation holding such permit.

d. Any trustee, by trust agreement to vote stock in such corporation holding such permit

e. Any person holding a license for the sale of intoxicating beverages.

f. Any member of an aseciation holding such license.

g. Any officer or director of a corporation holding such license.

h. Any person operating a public utility subject to grant of franchise or regulation by the state or any political subdivision thereof

i. Any member of an association operating such utility (members of non profit cooperative corporations not included.)

j. Any officer or director of a corporation opcrating stuch utility. 
EXPENDITURES

1. Expenditures may not be made for campaign purposes other than for personal travel and incidental expenses prior to noon of the first filing date for the nomination which candidate seeks. (Sec. 99.161 (2) (d)F.S.) ". "

2. No expenditure may be made or authorized unless there is money in the depository "to the credit of the compoign fund of the candidate sufficient to pay the amount." (Ch. 99.161 Sec. 6)

3. Written authorization is required for each expenditure, signed by the Campaign treasurer, accompanied by the certif. cate of the person claiming the payment which states the purpose of claim and that no other person is interested. "The written authorization, the certifieate and the order for payment shall be on the same piece of paper." (Ch. 99.161 written authorization, the certifical

4. Campaign Expenditures are limited to the following: (Ch. 99.172)

(1) Fee for qualifying.

(2) For his traveling expenses while campaigning or the legitimate traveling expenses of speakers in his behalf or of his campaign employees, or committee members.

(3) Stenographic work.

(4) Clerks at his compaign headquarters.

(5) Telegrams

(6) Telephones

(7) Postage

(8) Freight

(9) Express

(10) Stationery

(11) List of electors

(12) Office rent

(13) Newspaper advertising

(14) Advertising on television

(15) Advertising in magazines or other periodicals

(16) Advertising on billboards, on banners and on streamers

(17) Printing and the renting of halls in which to address the electors

(18) Radio time

(19) The renting or buying of public address equipment and the automotive equipment necessary to transport and operate it

(20) Compensation for campaign treasurer and/or campaign manager of the candidate at his main headquarters

(21) Compensation for poll watchers

(22) Hire of cars and drivers

\section{REPORTS OF EXPENDITURES AND CONTRIBUTIONS}

1. Campaign Treasurers must file reports of campaign expenditures and contributions as follows:

(1) For Governor and United States Senator: On MIonday of each week preceding the election,

(2) For all other offices-On the first Monday of each Month preceding the election,

Such Reports shall be filed with the officer before whom the candidate is required to qualify not later than noon of the day designated. Duplicate copy, duly certified, shall be filed by the same time with the Clerk of the Circuit Court in the County in which the candidate resides unless under the provisions of this subsection the original reports are filed with the Clerk. (Ch. 99.161 Section 8.) (d) (Sec, of State Form A-7)

(4) Should any candidate be unopposed for nomination for, or election to, any office after the time prescribed by law for qualifying then the obligation to file the above reports shall cease. (Sec. 99.161(8) (e)

\section{DEPOSITORY'S STATENENT AFTER ELECTION}

(1) Depository Statements containing original or true copy of deposit slips and original or true copy of all withdrawal orders, must be filed within fifteen days after primary with the officer before whom the candidate qualifies. (Ch. 99.161 Section 10) (Sec. of State Form A-8)

\section{WHEN AND WHERE TO QUALIFY}

Candidates for United States Senator, Representative in Congress, Govemor, Cabinet Officer, Justice of the Supreme Court, Judge of the District Court of Appeal, Circuit Judge, Railroad and Public Utilities Commissioner, State Attomey, State Senator, Member of the House of Representatives and all other candidates for State Office must file Oath, pay filing fee and committee Ascessment with the Secretary of State at any time after Noon February 20, 1962, but not later than Noon March 6, 1962

Candidates for County Offices must file oath, and receipt for party assessment with and pay filing fee to the Clerk of the Circuit Court of their respective counties at any time after Noon March 6, 1962, but not later than Noon March 20, 1962. 
Borm A-5

(All deposits to be made within 24 hours after contributions recelved, Sundays and holldays exceptad)

\section{CAMPAIGN DEPOSIT SLIP}

(to bo medo out be triplleato)

See 99.161, Sub. Sec. (5) Election Code 1955 Florida Statutes.

Deposited with: Bank

Cempargen Depository

Addreas

In the Campaign Fund of Namo of Cendideto

Address

Candidate for the office of

NAME OF CONTRIBUTOR

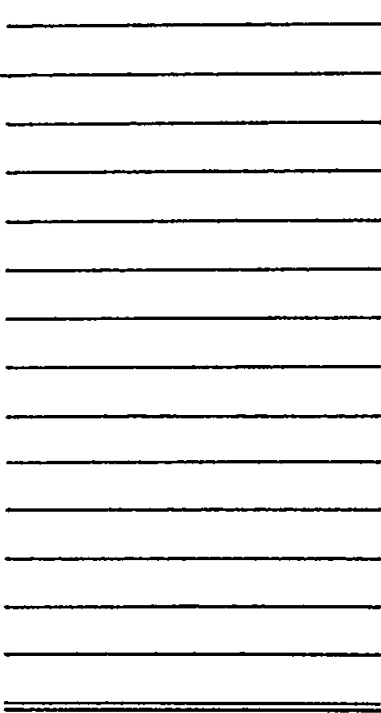

TOTAL AMOUNT OF THIS DEPOSIT.

I hereby certify that the sbove and foregoing deposit statement is true and correct.
AMOUNT CONTRINUTED
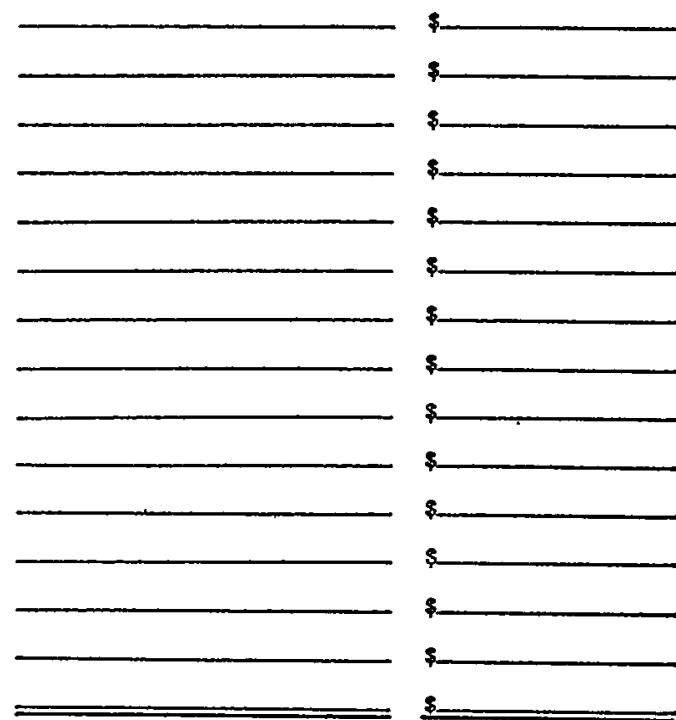

5
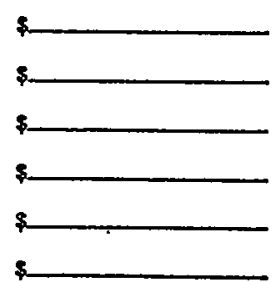

$\$$

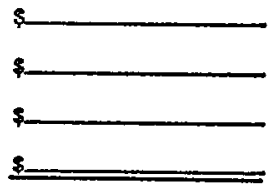

$\$$
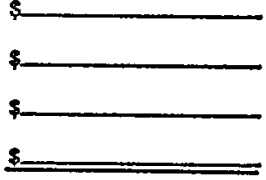

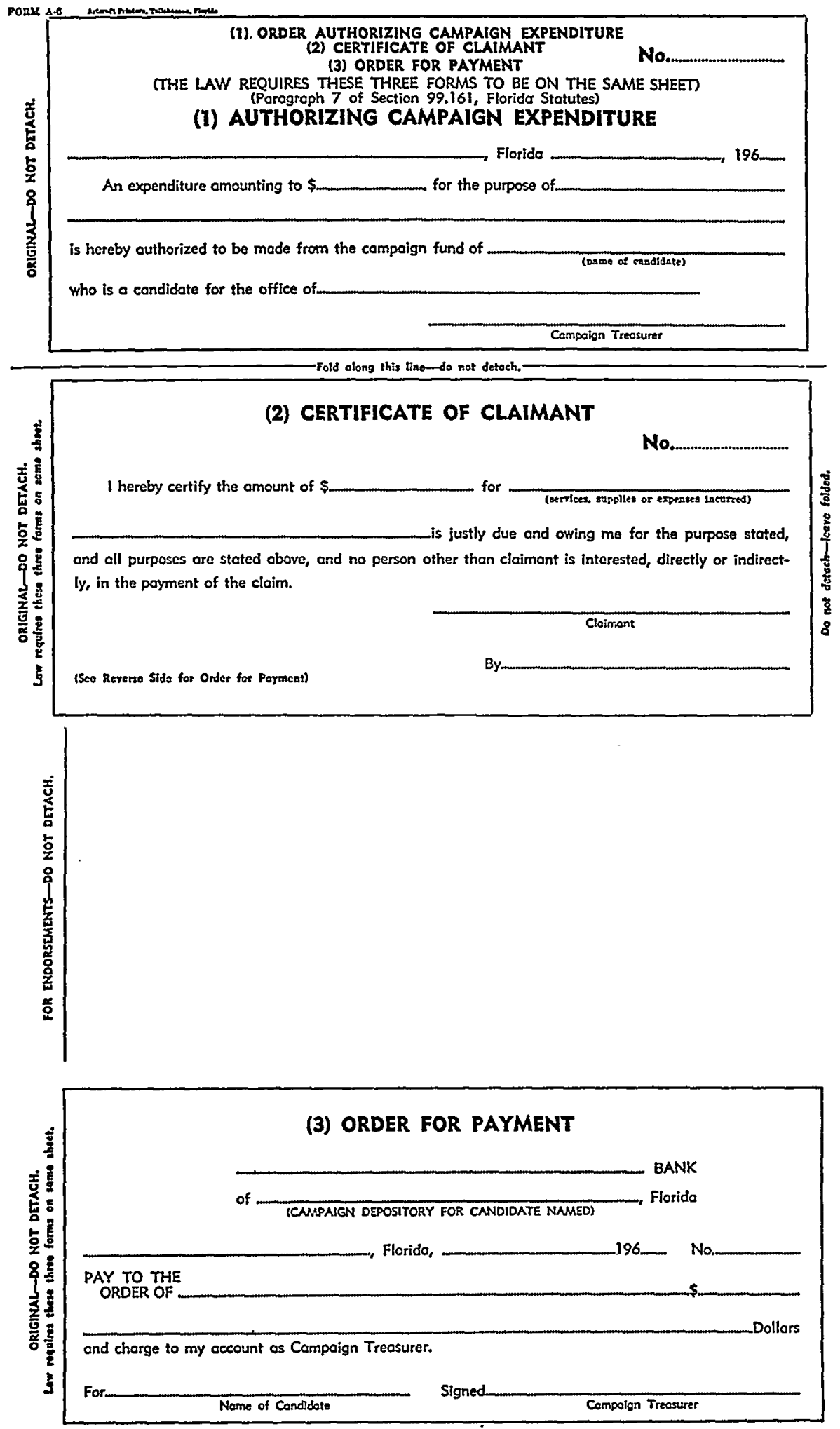


\section{CAMPAIGN TREASURER'S PRE-ELECTION REPORT TO THE SECRETARY OF STATE (OB CLERK OF CIRCUIT COURT IF YOU QUALIFIED WITI THAT OFFICIAL) (Bob-Section 8 of Seetioa 99.161 Floride statuta)}

Name:

Address:

Canditate For:

This report is a detailed statement of all expenditures, giving date, name of claimast, purposo asd amount of same. Also names of all contributors with dale and amount contributed to date of this report.

This report shall be made at the following intervals and not later than noon of the day designated for tho follow. ing offices from the date of appointment of the campaign treasurer to the date of the eloction or climination of tho candidate.

GOVERNOR and U. S. SENATOR-On Monday of each week preceding tha election.

All Other Offices-On the first Monday of each month preceding the clection.

(Sec list of expenditures allowed on reverse side of this report)

(Sce limit of contribution allowed on reverse side of this report)

List of all expenditures authorized, incurred or made to date of this report.

\begin{tabular}{|c|c|c|c|}
\hline Date & $\begin{array}{l}\text { Name and wddress of party to thom } \\
\text { expenditure is miles }\end{array}$ & Purpose of Expenditure & AMOUNR \\
\hline & & & \\
\hline & & & \\
\hline & & & \\
\hline & & & \\
\hline & & & \\
\hline & & & \\
\hline & & & \\
\hline & & & \\
\hline & & & \\
\hline
\end{tabular}

List of contributions (with names and addresses of contributors)

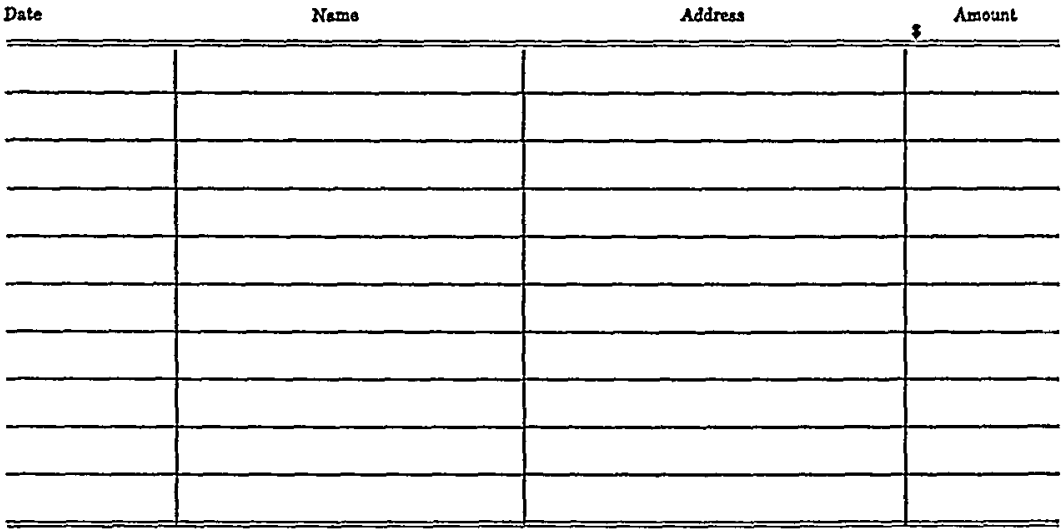

I hereby certify that the above and foregoing statconent is true and corroct: Dated at

Florida, this day of 196

$$
\text { BY. }
$$

Camplestgn Treasarer 